\title{
IMPROVING STUDENTS' SPEAKING PROFICIENCY BY USING SPEAKING BOARD GAMES FOR ELEMENTARY STUDENTS AT EDUPRANA LANGUAGE COURSE PALANGKARAYA KALIMANTAN TENGAH
}

\author{
NORHAYATI \\ Department of System Information, STMIK Palangka Raya \\ inoynorhayati@gmail.com
}

\begin{abstract}
Abstrak
There are so many techniques which can be implemented by teachers in order to support teaching learning process. Some techniques are also useful for improving students' speaking proficiency. In Eduprana Language Course, which offer Speak Out program for the young learners, the methods in practicing speaking mostly used role-play method. In this method, students are required to practice conversation based on the situations that are provided in module learnt. This method, somehow, make the practice of speaking be boring and monotone. In order to solve this problem, the teachers are required to be more creative so the class atmosphere be more interesting and students be more creative in speaking. The usage of game in teaching learning process has been known can give positive impact for learning experiences. So, in this study, the writer tried to implement the usage of speaking board games in order as an effort of improving students' speaking proficiency. The method of this study is class actions research, where in this study there are two cycles that are being conducted. The result of the study showed significant increasing point of pre-test and post-test of four variables in this study; vocabulary 2.51 to 3.11 , pronunciation 2.41 to 3.16, grammar 2.65 to 3.00, fluency 2.66 to 3.13. So, it can be concluded that; 1) it is important to provide activities which engage the students' participation in the speaking activities and give them more chance to speak, such as playing board games which attracts the students' attention and make them enthusiastic to join the lesson. 2) Playing board games engaged the students to speak up. When the students were playing the games, all of them had the same proportion to speak.
\end{abstract}

Keywords: Speaking proficiency, board game, language course

\section{INTRODUCTION}

The students who are trying to learn English as a foreign language are required to have proficiency in speaking skill. In spite of that, the teachers are demanded to use certain technique or strategy in teaching and improving this skill. In CLT (Communicative Language Teaching) approach, it provides various communicative activities in English language teaching. In reality, however, the activities of learning 
are the traditional models, such as reading aloud the dialogues/monologues from a written transcript, reciting texts, or doing some written exercises.

Eduprana Language Course is a local language course which has two languages program that are being offered; English and Japanese Languages. English course program are divided into two types, regular and private classes. The material which is being offered for regular classes are Real English, Speak Out and TOEFL Preparation.. The Speak Out program has 5 level, they are; starter, elementary, pre-intermediate, intermediate, advanced, In this study, the writer tried to do class action research for Speak Out program which are followed by 8 students.

Speaking is productive skill of language learning. It involves communicative performance, and other important elements, such as, pronunciation, intonation, grammar, vocabulary, etc. Brown and Yule (1999: 14) stated that speaking is depending on the complexity of the information to be communicated; however, the speaker sometimes finds it difficult to clarify what they want to say. Hughes (2006:144) stated that speaking is the first mode in which children acquire language, it is part of the daily involvement of most people with language activities, and it is the prime motor of language change.

Board games are familiar game types for children. This type of games mainly involves moving markers along a path (Lewis and Bedson, 1999). Monopoly, Snake and Ladders, and Ludo are the examples of popular board games. Almost all board games are the imitations of situations in real life. Board games have also been used to teach children basic fact and information about the world in which they live. (Provenzo, 1981: 2).

Using board games in language learning gives a lot of benefits. One of them is that board games are flexible. Chang and Cogswell (2008) state that board games are adaptable asset in the classroom because board games can be used as intended for native speakers, adapted to teach specific language forms and functions, adapted for various ESL/EFL contexts, age groups, proficiency levels, and content and adapted as communicative in the classroom. The games can also be adapted as a concept for making their own educational board game.

When using board games, it should be kept in mind how these five characteristics are exemplified in student interaction. Furthermore, it is important that lessons that implement board games should be composed of warm-up activities, formal instruction, tasks, and wrap-up/reflection activities that integrate all language 
skills to provide learners with a holistic language learning experience (Chang and Cogswell, 2008). In order to improve the excitements and interactions among the students in Speak Out program of starter level, so the writer is interested to apply board games in teaching learning process.

The objective of this study is to improve students' speaking skill in Speak Out program of starter level through speaking board games.

\section{RESEARCH METHOD}

The method of this study is Classroom Action Research, as Burns (2010:2) states that action research is a self-reflective, systematic and critical approach to enquiry by participants who are at the same members of the research community, which aims to identify problematic situations or issues considered by the participants to be worhty of investigation in order to bring about critically informed changes in practices.

This research was conducted in some cycles to solve the problems discovered in the teaching and learning process based on the observation and interview.

1. The subject of the study are the English teachers/tutors and students of Speak Out program of elementary level of Eduprana Language Course, 16 students (two classes).

2. There were two typed of data in this study, quantitative and qualitative data. The writer collected the quantitative data in the form of students' score during the pretest and the post-test. While the qualitative data were collected through the observation and interviews in the form of vignette and interview transcript to describe the implementation of the action process and the changes/the improvement after implementing the action.

3. The research has some techniques and some instruments to gain both qualitative and quantitative data. The techniques are; a. observation, b. interview, testing, and documenting study.

4. The research procedure that implemented can be seen as follow:

The research was conducted in more than one cycle which consists of four broad phases as suggested by Kemmis and Mc Taggart in Burns (2010: 8-9). The phases are: 


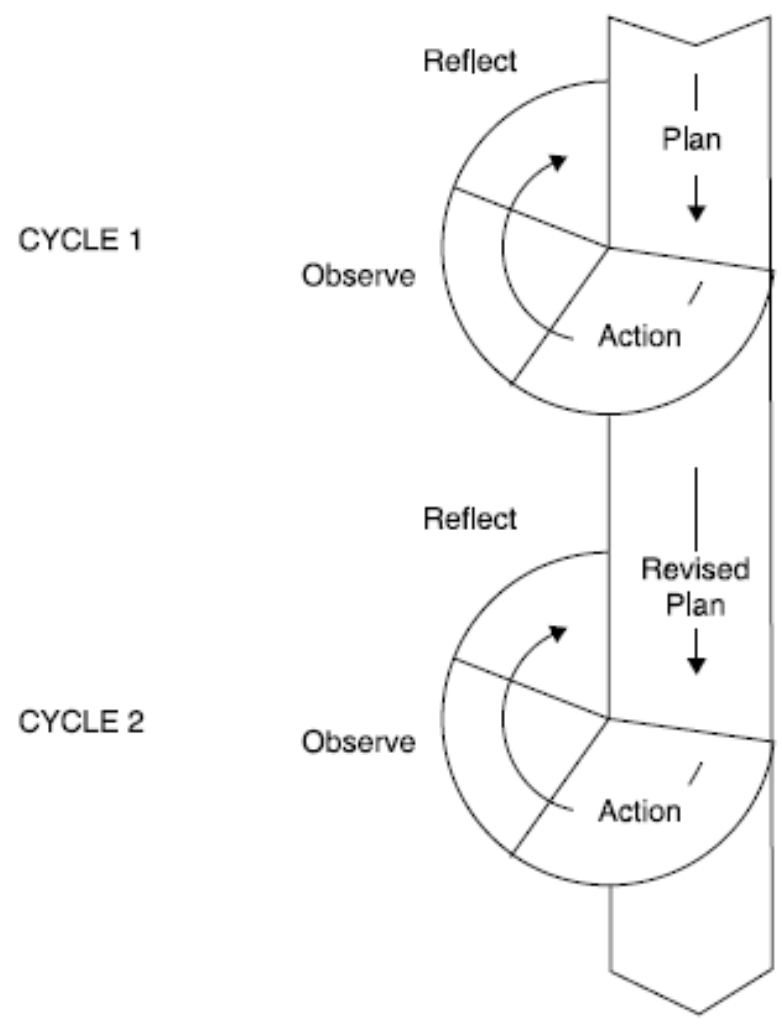

Figure 1: Action Research Cycles

a. Reconnaissance

It is the first step of conducting this research in which the writer determined the thematic concern of the research. The writer directly observed the teachinglearning process in the classroom. Then, the writer also had some interviews with the participants (the English teacher, the students) about the existing problems in the teaching-learning process. Based on the result of the observation and interview, the writer classified the existing problems.

b. Action

Planning, implementation, observation and reflection

\section{DISCUSSION AND RESULT}

\section{A. Discussion}

After observing the classroom activity and interviewing the English teacher and some students, the writer conducted the pre-test. The result of the pre-test was in the form of score which supports the main data in this study. When the writer conducted the pre-test, there were three participants who assessed the students' 
speaking performances. The aspects which were assessed are vocabulary, pronunciation, grammar and fluency. The maximum score for an aspect was 4 and the minimum score was 1 . The average score of pre-test are presented below.

Table 1: The Average Score of Pre-Test in Each Aspect

\begin{tabular}{|c|c|}
\hline Aspect & Mean (x) \\
\hline Fluently & 2.66 \\
\hline Pronunciation & 2.41 \\
\hline Vocabulary & 2.51 \\
\hline Grammar & 2.53 \\
\hline
\end{tabular}

From the table and above, the writer concluded that the students' scores of each aspect are low. The average score of each aspect was approximately 2 . Based on the scoring rubric, this number implies that; 1) The students spoke less fluidly and had few long breaks., 2) The students' speech was comprehensible but there were some mispronunciations., 3) The students used limited vocabularies., and 4) The students had many grammatical mistakes.

After discussing the result of the observation, the interviews and the students' scores of pre-test, the writer had identified the field problems found in the teaching and learning process. The field problems which occurred in the teaching and learning process are presented in the following table.

Table 2: The Most Urgent Problems

\begin{tabular}{|c|c|c|}
\hline No. & Field Problems & Code \\
\hline 1 & The students were not confident to speak English. & $\mathrm{S}$ \\
\hline 2 & The students were silent and reluctant to speak. & S \\
\hline 3 & The students did not speak fluently. & S \\
\hline 4 & The students had difficulties in using grammar. & S \\
\hline 5 & The students found difficulties in pronouncing some English words. & $\mathrm{S}$ \\
\hline 6 & The students lacked vocabulary. & S \\
\hline 7 & $\begin{array}{l}\text { The students were afraid of making mistakes when they are speaking in } \\
\text { English. }\end{array}$ & $\mathrm{S}$ \\
\hline 8 & $\begin{array}{l}\text { The students did not know how to say something using the English } \\
\text { expressions correctly. }\end{array}$ & S \\
\hline 9 & The students not fully participated in speaking activities. & S \\
\hline
\end{tabular}




\begin{tabular}{|c|l|c|}
\hline 10 & $\begin{array}{l}\text { The students often used Bahasa Indonesia to speak, especially to answer the } \\
\text { teacher's questions. }\end{array}$ & $\mathrm{S}$ \\
\hline 11 & The students got fewer chances to speak. & $\mathrm{S}$ \\
\hline 12 & The students had fewer practices. & $\mathrm{S}$ \\
\hline 13 & The students were not give a model of language. & $\mathrm{S}$ \\
\hline
\end{tabular}

S: Students, T: Teacher, Mtd: Method, Md: Media, Mtrl: Material

After weighing the field problems based on the urgency level, the research team selected the most feasible problems to solve. In this research, there were thirteen most feasible problems as showed in the following table.

Table 3: The Most Feasible Problems to Solve

\begin{tabular}{|c|l|c|}
\hline No. & \multicolumn{1}{|c|}{ Field Problems } & Code \\
\hline 1 & The students were not confident to speak English. & S \\
\hline 2 & The students were silent and reluctant to speak. & S \\
\hline 3 & The students did not speak fluently. & S \\
\hline 4 & The students had difficulties in using grammar. & S \\
\hline 5 & The students found difficulties in pronouncing some English words. & S \\
\hline 6 & The students lacked vocabulary. & S \\
\hline 7 & The students were afraid of making mistakes when they are speaking in English. & S \\
\hline 8 & The students did not know how to say something using the English expressions & S \\
\hline 9 & correctly. & The students not fully participated in speaking activities. \\
\hline 10 & The students got fewer chances to speak. & S \\
\hline 11 & The students had fewer practice. & S \\
\hline 12 & The students were not given a model of language. & Mtd \\
\hline 13 & The method used by teacher did not engage the students to speak up. & \\
\hline
\end{tabular}

\section{S: Students, Mtd: Method}

The research team designed the actions to solve the problems. Before designing the actions, the research team formulated the indicators of success that refer to the most feasible problems to solve. These indicators led the research team to design the actions. 
Table 4: Indicators of Success Formulations

\begin{tabular}{|c|l|}
\hline No. & \multicolumn{1}{|c|}{ Indicators of Success } \\
\hline 1 & The students become more confident and more active to speak English. \\
\hline 2 & The students speak more fluently. \\
\hline 3 & The students use grammar correctly. (speak more accurately) \\
\hline 4 & The students pronounce the words correctly. \\
\hline 5 & The students had varied vocabularies. \\
\hline 6 & The students are able to use expressions correctly. \\
\hline 7 & The students fully participate in speaking activities and get more chance to speak. \\
\hline
\end{tabular}

After formulating the indicators above, the research team designed the actions to achieve the indicators. First, to make the students more confident and more active to speak English needs a friendly atmosphere in the speaking activities. Second, to make the students speak more fluently requires more practices, so that the students could learn how to use new expressions using the right intonation and accurate pronunciation. Third, to make the students speak more accurately requires practices. By doing practices the students could learn how to speak accurately and fluently. Then, to make the students have more vocabularies needs some actions. The writer gave some activities in which they find new vocabularies, such as completing a dialogue. Next, to make the students able to use expressions the writer could provide activities in which they learn how to use the expressions after presenting them at the stage of presentation. Last, the students also have to participate more in the speaking activities. Thus, it needed to provide activities which engage the students' participation.

After designing the actions referred to the indicators, the writer summarized the actions that would be implemented to solve the problems, as follow:

1. Applying speaking board games

2. Giving listening activities to provide the model of expressions.

3. Giving the students some practices

4. Giving feedback and prompt if necessary

5. Using classroom English during the teaching and learning process 


\section{The Implementation of Cycle I}

Planning

The writer team planned to conduct the Cycle 1 in three meetings. Based on the results of the discussion of the research team, the action plans of Cycle I are; a) applying speaking board games, b) giving listening activities to provide the model of expressions, c) giving the students some practices, d) giving feedback and prompt if necessary and e) using classroom English during the teaching and learning process.

The writer also planned the activities that the students are going to do in the first cycle as follow. (the more complete form is attached in the course grid and lesson plans)

1) Meeting 1

Topic: 'About Me'

Material: asking for information, giving information, denying information

Activities; a) introducing the topic of the material, b) presenting the materials,

c)doing some practices, d) playing speaking board games, and f) concluding

2) Meeting 2

Topic: 'Entertainment'

Material: asking for an opinion, giving an opinion

Activities; a) introducing the topic of the material, b) presenting the materials,

c)doing some practices, d) playing speaking board games, and f) concluding

3) Meeting 3

Topic: 'Hot Issues'

Material: agreeing and disagreeing

Activities; a) introducing the topic of the material, b) presenting the materials,

c)doing some practices, d) playing speaking board games, and f) concluding

The implementation of Cycle I were on September $5^{\text {th }}, 7^{\text {th }} 2016$. The English teacher, the students and the research collaborator participated in the research study to collect the data. 
Table 5: The Comparison Between the Actions in Cycle I and Cycle II

\begin{tabular}{|l|l|}
\hline \multicolumn{1}{|c|}{ Cycle I } & \multicolumn{1}{c|}{ Cycle II } \\
\hline $\begin{array}{l}\text { Using classroom English during the } \\
\text { teaching and learning process }\end{array}$ & $\begin{array}{l}\text { Using classroom English during } \\
\text { the teaching and learning process }\end{array}$ \\
\hline $\begin{array}{l}\text { Giving listening activities to provide } \\
\text { the model of expressions }\end{array}$ & $\begin{array}{l}\text { Giving listening activities to } \\
\text { provide the model of expressions }\end{array}$ \\
\hline Giving the students some practices & Giving the students some practices \\
\hline Applying speaking board games & Applying speaking board games \\
\hline Giving feedback and prompt if & $\begin{array}{l}\text { Giving feedback and prompt if } \\
\text { necessary }\end{array}$ \\
\hline- & $\begin{array}{l}\text { Giving the students chance to } \\
\text { correct their friends and their own } \\
\text { mistake }\end{array}$ \\
\hline
\end{tabular}

The writer also had planned the activities that the students were going to do during the teaching and learning process. The activities are presented below.

4) Meeting 4

Topic: At Home

Material: making a request

Activities; a) introducing the topic of the material, b) presenting the materials, c) doing some practices, d) playing speaking board games, and f) concluding

5) Meeting 5

Topic: Me and Friends

Material: offering

Activities; a) introducing the topic of the material, b) presenting the materials, c) doing some practices, d) playing speaking board games, and f) concluding

The implementation of Cycle II were on Oktober $3^{\text {rd }}, 5^{\text {th }} 2016$. The English teacher, the students and the research collaborator participated in the research study to collect the data.

Table 6: The Change Result of the Implementation of Cycle II and the Conclusion.

\begin{tabular}{|l|l|lr|}
\hline \multicolumn{1}{|c|}{$\begin{array}{c}\text { Condition before the } \\
\text { implementation of Cycle II }\end{array}$} & \multicolumn{1}{c|}{$\begin{array}{c}\text { Condition after the } \\
\text { implementation of Cycle II }\end{array}$} & \multicolumn{2}{c|}{ Conclusion } \\
\hline $\begin{array}{l}\text { The students became more } \\
\text { confident and more active to }\end{array}$ & $\begin{array}{l}\text { The students became more } \\
\text { confident and more active to speak }\end{array}$ & $\begin{array}{r}\text { The students } \\
\text { became more }\end{array}$ \\
\hline
\end{tabular}




\begin{tabular}{|c|c|c|}
\hline $\begin{array}{l}\text { speak English. When the researcher } \\
\text { asked some questions in English, } \\
\text { they could give responses in } \\
\text { English as well. However, they } \\
\text { sometimes still used Bahasa } \\
\text { Indonesia to give their responds. }\end{array}$ & $\begin{array}{l}\text { English. The students could give } \\
\text { responds comprehensively and } \\
\text { they attempted to use English } \\
\text { accurately, even the researcher } \\
\text { reduced the use of Bahasa } \\
\text { Indonesia in the teaching and } \\
\text { learning process. }\end{array}$ & $\begin{array}{l}\text { confident and } \\
\text { more active to } \\
\text { speak English. }\end{array}$ \\
\hline $\begin{array}{l}\text { The students spoke more } \\
\text { fluently and automatically and had } \\
\text { less frequent long breaks. }\end{array}$ & $\begin{array}{l}\text { The students spoke more } \\
\text { fluently. They could minimize } \\
\text { long breaks and speak fluidly. }\end{array}$ & $\begin{array}{l}\text { The students } \\
\text { spoke more } \\
\text { fluently. }\end{array}$ \\
\hline $\begin{array}{l}\text { The students improved their } \\
\text { pronunciation. They attempted to } \\
\text { have accurate pronunciation } \\
\text { and their speech was } \\
\text { comprehensible, but sometimes } \\
\text { they still had some } \\
\text { mispronunciations. }\end{array}$ & $\begin{array}{l}\text { The students improved their } \\
\text { pronunciation. They attempted to } \\
\text { have accurate pronunciation and } \\
\text { their speech was } \\
\text { comprehensible. They got more } \\
\text { chance to correct their own or } \\
\text { their friend's mispronunciations } \\
\text { and became aware of their } \\
\text { pronunciation. }\end{array}$ & $\begin{array}{l}\text { The students } \\
\text { improved their } \\
\text { pronunciation. }\end{array}$ \\
\hline $\begin{array}{l}\text { The students had more } \\
\text { vocabularies. They could gather } \\
\text { new vocabularies in the } \\
\text { classroom activities. }\end{array}$ & $\begin{array}{l}\text { The students had more } \\
\text { vocabularies. They could gather } \\
\text { new vocabularies in the } \\
\text { classroom activities. They } \\
\text { attempted to use new } \\
\text { vocabularies. }\end{array}$ & $\begin{array}{l}\text { The students } \\
\text { had more } \\
\text { vocabularies. }\end{array}$ \\
\hline $\begin{array}{l}\text { The students were able to use } \\
\text { the expressions correctly. They } \\
\text { knew how to use expressions to } \\
\text { speak based on the functions of } \\
\text { each expressions. }\end{array}$ & $\begin{array}{l}\text { The students were able to use } \\
\text { the expressions correctly. They } \\
\text { knew how to use expressions to } \\
\text { speak based on the functions of } \\
\text { each expressions. They could } \\
\text { speak using the expressions } \\
\text { comprehensively. }\end{array}$ & $\begin{array}{l}\text { The students } \\
\text { were able to use } \\
\text { the expressions } \\
\text { correctly. }\end{array}$ \\
\hline $\begin{array}{l}\text { The students participated More } \\
\text { in the speaking activities and got } \\
\text { more chance to speak. They } \\
\text { were interested, excited, and }\end{array}$ & $\begin{array}{l}\text { The students participated more } \\
\text { in the speaking activities and got } \\
\text { more chance to speak. They were } \\
\text { interested, excited, and enthusiastic }\end{array}$ & $\begin{array}{l}\text { The students } \\
\text { participated more } \\
\text { in the speaking } \\
\text { activities and got }\end{array}$ \\
\hline
\end{tabular}




\begin{tabular}{l|l|l|}
\hline $\begin{array}{l}\text { enthusiastic to learn through } \\
\text { playing board games. However, } \\
\text { they seemed bored playing the } \\
\text { same games in every lesson. }\end{array}$ & games. & $\begin{array}{l}\text { more chance to } \\
\text { speak. }\end{array}$ \\
\hline
\end{tabular}

In the fifth meeting the writer also used English to start the lesson. The writer also used classroom English to introduce the material that the students were going to learn at the day. When the writer asked the students some questions, they could give the responds comprehensively. The comparing score of pre-test and post-test can be shown as follow:

\begin{tabular}{|l|c|c|}
\hline \multicolumn{1}{|c|}{ Aspect } & $\begin{array}{c}\text { Mean (x) Score of } \\
\text { Pre-Test }\end{array}$ & $\begin{array}{c}\text { Mean (x) Score } \\
\text { of Post-Test }\end{array}$ \\
\hline Vocabulary & 2.51 & 3.11 \\
\hline Pronunciation & 2.41 & 3.16 \\
\hline Grammar & 2.65 & 3.00 \\
\hline Fluency & 2.66 & 3.13 \\
\hline
\end{tabular}

\section{DISCUSSION}

The study was conducted to solve the problems related to speaking skills through speaking board games. The research consisted of some steps. They are reconnaissance, actions which consist of planning, implementations and reflections. By conducting this research, it was found that; 1) the use of speaking board games to teach speaking which was combined with other actions improved the students' confidence and made the student more active to speak, 2) the use of speaking board games to teach speaking which was combined with other actions improved the students' fluency, 3) the use of speaking board games to teach speaking which was combined with other actions improved the students' accuracy, 4) the use of speaking board games to teach speaking which was combined with other actions improved the students' pronunciation. They also got the model of language in the spoken form, so they could get accurate pronunciation.

There are also some implications due to the result of this research. The implications of the actions are; 1). It is found that board games could create a friendly atmosphere and encouraged the students to get more confidence. 2) board 
games could improve the students' fluency implies that it is important to give the students activities which can improve their fluency, as it is one of criteria of good speaking skills.3) board games could improve the students' accuracy. Thus, it is important to give the students activities which improve the students' accuracy. It is also useful to give the students chance to correct their own and their friend' mistakes to make them more aware of their accuracy. 4) board games could improve the students' pronunciation. 5) board games could improve the students' vocabulary. 6) board games could help the students to learn how to use language expressions easily, joyfully and communicatively. 7) board games could improve the students' participation.

\section{ACKNOWLEDGEMENTS}

Many thanks to all whose have contributed encouragements, and the writer would like to give appreciation to:

1. Tutors/teachers at Eduprana Language Course

2. Students of Elementary level of Real Life English at Eduprana Language Course

\section{BIBLIOGRAPHY}

Chang, Shelley and Jenny Cogswell, 2008. Using Board Games in the Language Classroom TESOL.

Lewis, Gordon and Gunther Bedson. 2008. Games for Children. Oxford: Oxford University Press.

Provenzo, A. Baker and Eugene F. P., Jr. 1981. Favorite Board Games You Can Make and Play. New York: Dover Publication Inc.

Richards, Jack C. and Theodore Rodgers S. 2001.Approaches and Methods in Language Teaching.Cambridge: Cambridge University Press.

Sugar, Steve and Kim K. Sugar. 2002. Primary Games: Experiential Learning Activities for Teaching Children K-8. San Francisco, CA: Jossey-Bass.

Thi, Nguyen Thanh and Khuat Thi Thu Nga. 2003. Learning Vocabulary through Games. Asian EFL Journal. http://www.asian-efljournal.com/dec_03_vn.pdf

Toth, Maria. 1995. Heinemann Games for Children. Oxford: Heinemann Publishers.

Wright, Andrew., David Betteridge and Michael Buckby. 1994. Games for Language Learning. Cambridge: Cambridge University Press 